\title{
Perspectives and Achievement of EFL Students in Teaching Culture via Two Modes: Books vs. Books plus Films
}

\author{
Robab Khosravi \\ English Language Department, University of Zanjan, Iran \\ Mehdi Moharami \\ English Language Department, University of Zanjan, Iran \\ Giti Karimkhanlouei \\ Zanjan University of Medical Sciences, Iran
}

\begin{abstract}
Cultural education is a fundamental, often overlooked part of learning a language. Teaching culture in the EFL classroom, however, remains a challenge because culture is a complex and evasive concept. Ideally, maximal exposure of the learner to the target culture would be interacting directly with the native speakers. In the classroom, however, the sociocultural context can be re-created. A literature of a nation, one may claim, incorporates a major part of its cultural heritage. The main objective of this study was to investigate the relationship between the achievements of EFL learners through exposure to culture via reading the simplified version of a literary text plus (for the experimental group) watching its filmic adaptation. This goal was met by asking the students to take multiple-choice tests based on the literary text. The results indicated that using cultural tools enhances learners' achievement in different regards, including reading comprehension, its durability, and the degree of the student satisfaction.
\end{abstract}

Index Terms — culture education, reading comprehension, EFL learner, Jane Eyre, learning durability

\section{INTRODUCTION}

Effective communication is not just exchanging information, but sharing perspectives, experiences, and ways of thinking. Teaching culture can facilitate a more effective communication, butthis requires time and extra effort on behalf of the teacher. In the past, traditional methods of teaching culture included Grammar Translation Method (which focused on the target culture's literature) and Communicative Approach. But these methods offered only limited, sporadic exposures to culture.

To understand a culture, it is essential to understand its components. Mirroring a nation's identity, culture incorporates its history and geography, art and literature, perspectives, practices and products.Literature, as a cultural element, encompasses a nation's values, ideas, and morals. Literary works are remarkably rich in cultural elements.But studying a literary text in order to grasp its cultural aspects requires considerable time. A literary text, on the other hand, is written by a famous writer who uses sophisticated, sometimes ornamented language - which is not easily accessible to the learners. Using filmic adaptations from literary classics can be a strategy or technique for teaching culture in the classroom. Accompanying a literary text(which is often rich in cultural information) with its filmed adaptation (which can induce memorable reactions for EFL learners) allows the teacher to budget his/her timeandbridge the gap between language and learning.

In this study, Charlotte Bronte's classic romance, Jane Eyre, is chosen as the literary text. The book ranks 10 in the BBC Big Read list(which was a survey carried out in the UK to find the most popular novels of all time). Many simplified versions, as well as filmic adaptations of the book are available in the market.

\section{PRevious Studies}

\section{A. Background on Teaching Culture}

As Thanasoulas observes, "Effective communication is more than a matter of language proficiency and that, apart from enhancing and enriching communicative competence, cultural competence can also lead to empathy and respect toward different cultures as well as promote objectivity and cultural perspicacity" (p. 1). It is difficult to draw distinct boundaries between foreign language learning and foreign culture learning. Culture and language are inseparable which is to say that culture is already being taught implicitly. Larsen-Freeman (2001) regard culture as a fifth skill in addition to reading, writing, speaking and listening; Kramsch (1993) argues that culture is not just the fifth skill or even an aspect of communicative competence, but that culture is the fundamentalaspect of all one knows and does: 
"Culture in language learning is not an expendable fifth skill, tacked on, so to speak, to the teaching of speaking, listening, reading, and writing. It is always in the background, right from day one, ready to unsettle the good language learners when they expect it least, making evident the limitations of their hard-won communicative competence, challenging their ability to make sense of the world around them" (Kramsch, 1993, p. 1).

Such eminent scholars as Hall (1959), Seelye (1984), Steele (1989), Kramsch (1993), and Lessard-Clouston (1997) have argued that reaching culture in the classroom is highly important. Culture Bound, (1986) edited by J. M. Valdes makes an endeavor to highlight the importance of incorporating culture into the classroom. In her influential book, Context and Culture in Language Teaching Claire Kramsch addressed the educational challenges of teaching culture, and argued that cultural education is fundamental for communicative competence. In Teaching Culture: Perspectives in Practice Patrick R. Moran presented authentic, engaging classroom experiences to show how language and culture are intricately interwoven. Why teach culture, and how to incorporate it into the classroom? Before answering this question, we need to come up with a definition of culture, however tentative it may be.

\section{B. Definition of Culture}

The National Center for Cultural Competence defines culture as an "integrated pattern of human behavior that includes thoughts, communications, languages, practices, beliefs, values, customs, courtesies, rituals, manners of interacting and roles, relationships and expected behaviors of a racial, ethnic, religious or social group; and the ability to transmit the above to succeeding generations." Webster's Dictionary defines culture as the concepts, habits, skills, arts, instruments, institutions, etc, of a given people in a given period.

According to Hinkel (2001), culture includes rhetorical structure of texts, socio-cultural behaviors, speech acts, etc. Hinkel distinguishes between invisible and visible cultures. Visible culture, he argues, is readily apparent; itmanifests incodes of dressing, cooking, celebrations, customs andways of life, etc. The more complex invisible culture, however,can be found in social norms, perspectives, beliefs, convictions and values.

It is essential to make a distinction between Big C Culture and small c culture. While the former refers to music, literature, and arts in general, the latter marks everyday life habits and behaviors of a certain people. Kramsch refers to the conviction that "language learners are supposed to teach nothing but language; culture is reserved for the professors of literature" (2013, p. 58). But it is impossible to draw a distinct line between these two categories. If we are to confine literature to texts that are meant to be read, interpreted and analyzed by literary scholars, then literature will approach philosophy and science which are universal. But literature of a distinct people is not void of their local morals, values, and ways of thinking and behaving. As Peterson and Coltrane have observed,

"Language learners need to be aware, for example, of the culturally appropriate ways to address people, express gratitude, make requests, and agree or disagree with someone. They should know that behaviors and intonation patterns that are appropriate in their own speech community may be perceived differently by members of the target language speech community. They have to understand that, in order for communication to be successful, language use must be associated with other culturally appropriate behavior" (2003, p. 1).

When students watch the filmic adaptation of a literary text, technology makes cultural education a more immediate and pleasurable objective.

\section{Literature and Films as Tools for Teaching Culture}

Tools and techniques for teaching culture are various. They include authentic material, convention clusters, role play, culture capsules, internet technologies, semantic mapping, ethnographic studies, literature, film, reading and realia, etc. Innovative methods may seek to combine some of these materials to save time and facilitate a deeper cultural insight for the students. As Lessard-Clouston (1997) notes, there was a period of time in which people learned a foreign language in order to study its literature. Learning or teaching literature was neglected for a period of time (Duff and Maley, 1991), before it was it was revived again in the 1980s.

Scott \& Huntington (2000) carried out a study to establish the quality and level of recollection of two groups of students. One group studied a fact sheet about Côte D'Ivoire, while the other group studied a poem on colonialism in Côte D'Ivoire. The results showed that the second group showed empathy towards the Côte D'Ivoire people and their history, whereas the first group recollected little information about them.

Films can be ideal tools which make a (potentially challenging) literary text more accessible to EFL students. Zoreda and Vivaldo-Lima published an article in 2008 on teaching English using a graded literary reader and its filmic adaptation. Their study showed that, using a simplified novel and its film version helps the students interact more enthusiastically and critically with the target culture. Students achieved significant gains in cultural competence after incorporating videos from the target culture in the modules (Herron, Cole, Corrie, \& Dubreil, 1999).

The advantage of using films is that they offer students an opportunity to witness behaviors, reactions, and attitudes that may not beobvious in texts. Films encapsulate they way people feel, think, greet, and react in a culture. Films also connect students with language and cultural issues simultaneously (Stephens, 2001), such as depicting "conversational timing or turn-taking in conversation" (Peterson and Coltrane, 2003, p. 2).

Teaching a language is more than teaching its grammar, phonology, and lexis. Teaching cultural norms in a nonjudgmental way is of prime significance. Linguistic competence alone is not enough for learners of a language to be competent in that language (Krasner, 1999). Filmic adaptations allow students to observe a variety of cultural 
interactions. Teaching culture is not new but incorporating culture into the classroom requires careful organization and a well-designed frame. Using tools, strategies and technology helps to enrich the students' social insight because certain day-to-day interactions such as greeting, addressing, thanking, saying farewell, etc require more than just producing grammatically correct structures. As Thanasoulas argues, "For scholars and laymen alike, cultural competence, i.e., the knowledge of the conventions, customs, beliefs, and systems of meaning of another country, is indisputably an integral part of foreign language learning, and many teachers have seen it as their goal to incorporate the teaching of culture into the foreign language curriculum" (2001, p. 1).

\section{THE PRESENT STUDY}

This study aims at seeking the relationship between using literary text plus its film adaption (as tools for teaching culture) and students' reading comprehension and the learning durability.

\section{A. Research Questions}

1) Is there any significant relationship between showing film adaption and students' comprehension?

2) Is there any significant relationship between teaching by using film and students' learning durability?

3) Is there any significant relationship between teaching by using film and students' enthusiasiam?

\section{B. Method}

\section{Participants and Setting}

The subjects of this study included 80 English learners from Zabansara Language School in Iran. Upper-intermediate and advanced students were selected - as they werebelieved to be able to speak and write English with a good command of grammatical structure and vocabulary. These learners were divided in one control group and one experimental. Of this pool of subjects, 46 were female and 34 male. Their age range was $15-24$.

\section{Instrumentation}

The instruments used in this study were similar in both experimental and control groups, except that theexperimental group received a DVD that was afilm based on the novel Jane Eyre written by Charlotte Bronte. The film was directed by Cary Joji Fukuanaga and produced by Focus Feature in association with BBC and RUBY Film Production. The script for the film has been rewritten (supervised by Sylvia Parker). Other instruments in this research were same for both groups (this included Oxford Bookworm Library Stage 6: Jane Eyre retold by Clare West. The book contains 2500 head words).

In order to test students' achievement, for each Chapter of the book (taught in a single session), 10 multiple-choice questions were prepared. At the end of each session, the students were asked to answera multiple choice testthat incuded 10 items. This would be to say thatstudents answered 100items in total by the end of the course.

In the final session, the researchers administered an interview in order to find out the level of the learners' satisfaction regarding this mode of instruction.In this vein, a questionnaire with graded answerswas handed to students (which embarked on measuring learners' level of satisfactionbythree factors: group dynamics, tutor facilitators, and learning material).

Data CollectionProcedure

The students were divided into two main groups: an experimental and a control group. The classes were taught by the researchers.

The course book contained 10 Chapters, and each session the teacher covered only one Chapter. Students were asked to read a previously designated Chapterbefore coming to class. Then they were encouraged todiscussthe Chapter with other students and share their understanding of the Chapter.

To check the understanding of the students of the content of each session, a 6-minute Test (which included 10 items) was administered.However, in the last session a comprehensive test of the ingredients of all sessions was administered. This also included 10 items. Meanwhile, an interview was also carried out in the last session to uncover the learners'views on the effectiveness of the course and the level of their satisfaction. This procedure was descriptive and designed on a Likert scale.

\section{Data Analysis}

SPSS version 16 was used to analyze the collected data. The reliability of the tests was estimated via Cronbach Alpha. Statistical analyses and both descriptive and inferential statistics were used totest the hypothesis:

Ho1: There is a positive relationship between teaching by using films and students' comprehension level.

Ho2: There isa positive relationship between teaching by using films and students' learning durabilty.

Ho3: There is a positive relationship between teaching by using films and students' level of intrest.

\section{RESULTS}

\section{A. Test Reliability and Groups' Homogeneity}


As students were nominated by different teachers in the Language School, it could be ensured that all participants were at same level of study and there was no need to take placement test before execution of study and they all were in upper-intermediate level of study.

We have got 10 tests which each test contain 10 multiple-choice questions. Cronbach's Alpha is used to test reliability of our tests and it is calculated by this formula: ${ }_{\alpha}=\frac{K}{k-1}\left(1-\frac{\sum s_{l}^{2}}{s_{r u m}^{2}}\right)$ and reliability of 100 items test was 0.701 and it proved that our tests were reliable.

\section{B. Investigation of Research Question 1}

Research question 1 asked whether there is significant relationship between using film and students learning. To answer this question at first a group statistics carried out.The comparison of the means of the control and experimental groups indicated that the difference between means of these two groups was significant.

TABLE 1

GROUP STATISTICS

\begin{tabular}{|ll|l|l|l|l|}
\hline \multicolumn{2}{|c|}{ group } & $\mathrm{N}$ & Mean & Std. Deviation & Std. Error Mean \\
\hline \multirow{2}{*}{ Learning } & control & 40 & 80.7250 & 8.59036 & 1.35825 \\
& experimental & 40 & 90.1750 & 6.63668 & 1.04935 \\
\hline
\end{tabular}

To further examine the data, T-test was used. T-test is the test of the significance of the difference between two means. In this study, the learning of the participants in the experimental and control groups were compared to see if there wasa significant difference. The results of the t-test showed that the experimental group outperformed the control group in all multiple-choice tests.

TABLE 2

INDEPENDENT SAMPLES TEST

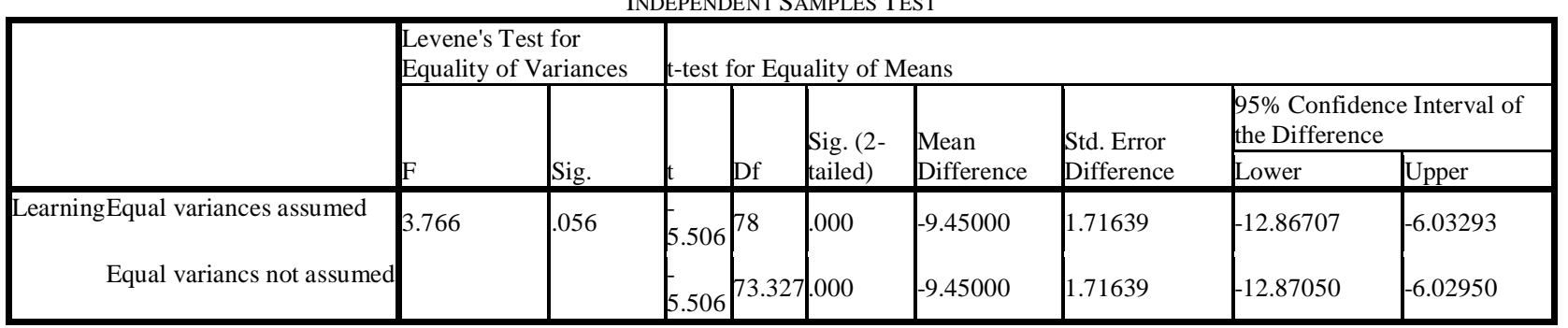

The t-test (Table 2) illustrates significance value of .056 and $\leq .05$, which means that Levene's Test was reliable. It also indicates that the two groups had different achievement levels (because of using two different modes of instruction). This is to say that theachievement level was less inthecontrol group as compared to the experimental group.

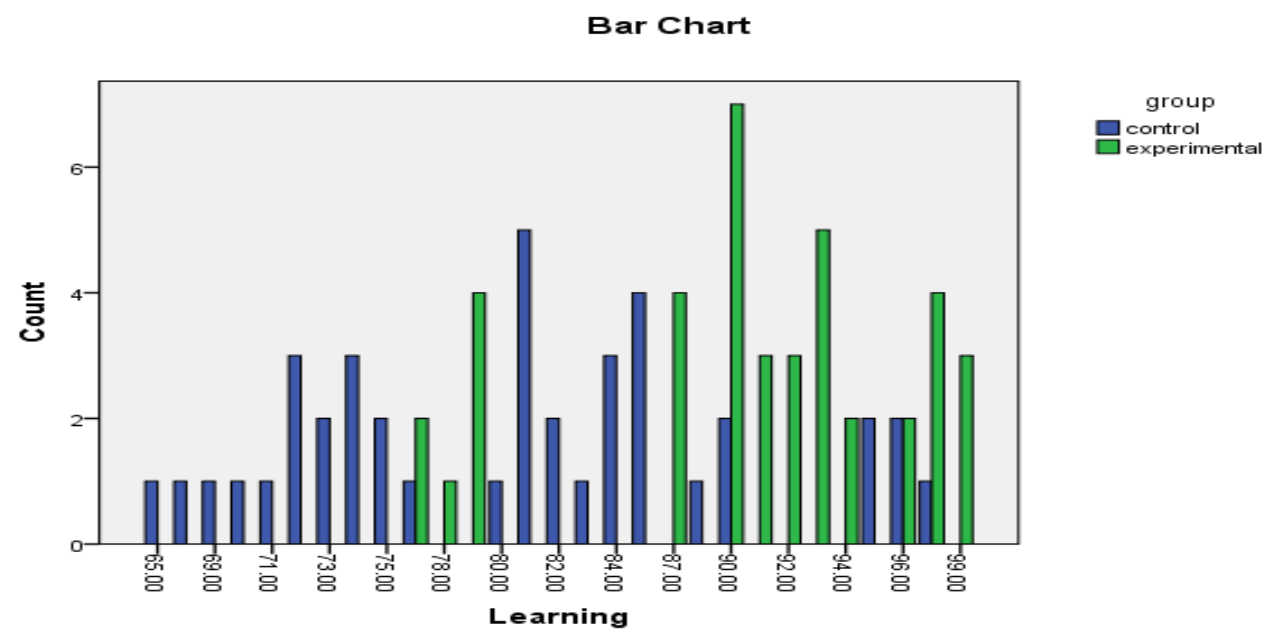

Figure 1

Figure 1isanillustration of both experimental and control groups in terms of their level of achievement and learning. As it is shown, bars scattering for the students' learning in the experimental group is in a higher level as compared to that of the control group. 


\section{Investigation of Research Question 2}

In order to investigate second research question that there is significant relationship between using film and students learning durability, all steps for first question was repeated but only for the last session test. Because last session's test was a comprehensive test from all Chapters and students had to recall their learning from past to answers the questions. So anothergroup statisticsfrom students' answers in the final test was run. The comparison of the means of the control and experimental groups in this test indicated that the difference between means of these two groups was significant and that the experimental groups had a more durable learning.

TABLE 3

GROUP STATISTICS

\begin{tabular}{|ll|l|l|l|l|}
\hline \multicolumn{2}{|c|}{ group } & $\mathrm{N}$ & Mean & Std. Deviation & Std. Error Mean \\
\hline \multirow{2}{*}{ Durability } & control & 40 & 83.3500 & 6.76549 & 1.06972 \\
& experimental & 40 & 92.2500 & 3.84808 & .60843 \\
\hline
\end{tabular}

To further examination of data another T-test base on students' last session test was run.

TABLE 4

INDEPENDENT SAMPLES TEST

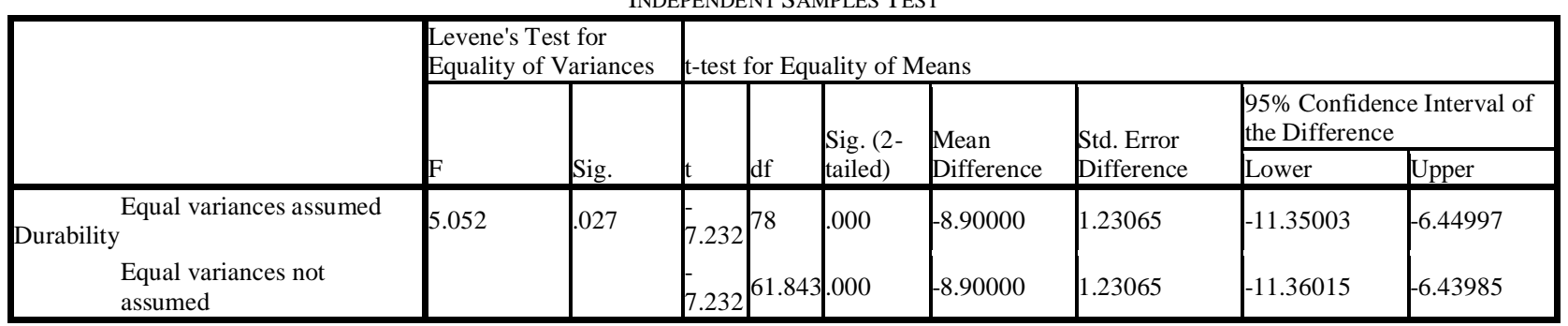

The T-test inTable 4 illustrates significance of .027 and $\geq .05$.,indicating that Levene's Test is not reliable, so we used the second line of data and the hypothesis of equity in mean $(=0.05)$ is rejected; it means that the two groups had different levels in learning durability. Due to the fact that the confidence interval of the difference was negative, we conclude that learning durability in control group was lessthan that of the experimental.

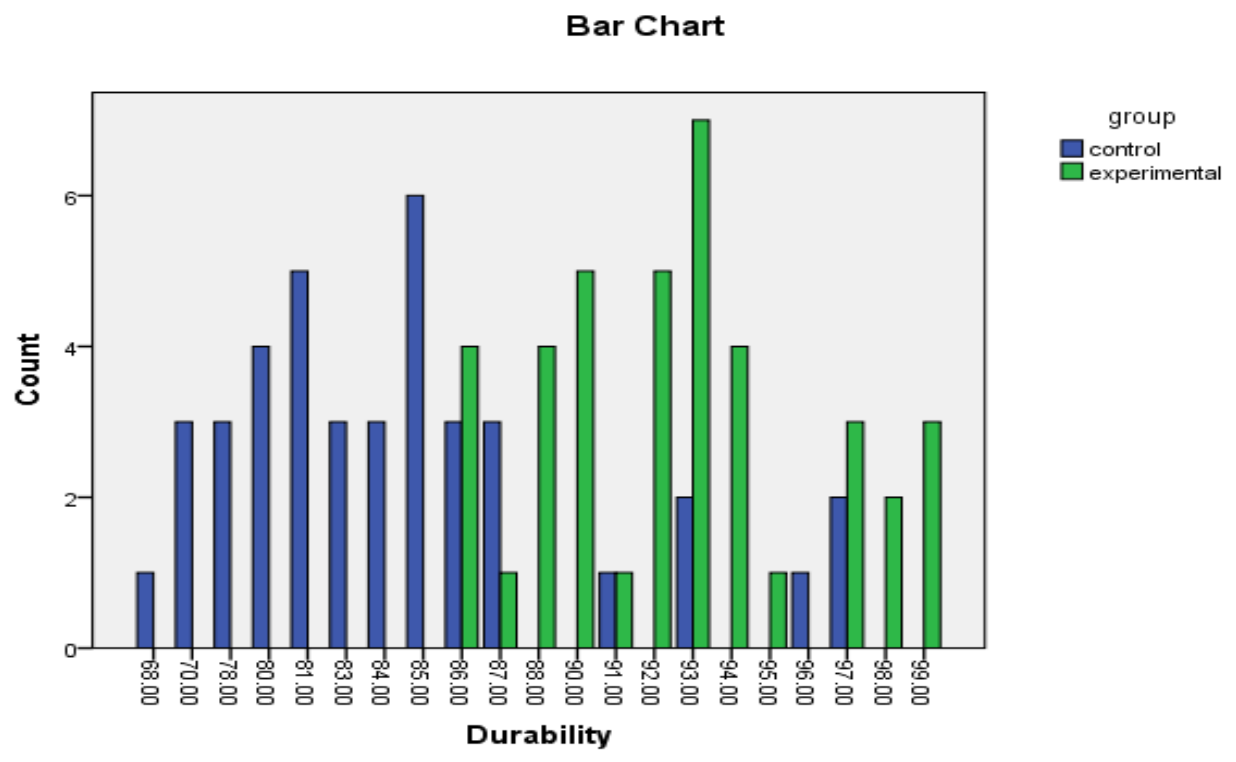

Figure 2

Figure 2 is a comparative mirror of both experimental and control groups' learning durability. As it is shown, bars scattering for students' learning durability in theexperimental group are at higher levels; yet in thecontrolgroup the bars are rather low.

\section{Investigation of Research Question 3}


To find out third research question, there is significant relationship between using film in teaching and students' interest. At first a group statistics base on students' interview was carried out. The comparison of the means of the control and experimental groups in this test indicated that the difference between means of these two groups was significant and that the experimental groups had a more interest in learning in this way.

Independent Samples Test

TABLE 5

GROUP STATISTICS

\begin{tabular}{|ll|l|l|l|l|}
\hline & Group & $\mathrm{N}$ & Mean & Std. Deviation & Std. Error Mean \\
\hline Interestedness & Control & 40 & 2.8750 & .82236 & .13003 \\
& Experimental & 40 & 3.9000 & 1.27702 & .20191 \\
\hline
\end{tabular}

To further examination of data another T-test base on students' interview was run.

TABLE 6

INDEPENDENT SAMPLES TEST

\begin{tabular}{|c|c|c|c|c|c|c|c|c|c|}
\hline & \multicolumn{2}{|c|}{$\begin{array}{l}\text { Levene's Test for } \\
\text { Equality of Variances }\end{array}$} & \multicolumn{7}{|c|}{ T-test for Equality of Means } \\
\hline & \multirow[b]{2}{*}{$\mathrm{F}$} & \multirow[b]{2}{*}{ Sig. } & \multirow[b]{2}{*}{$\mathrm{t}$} & \multirow[b]{2}{*}{ Df } & \multirow{2}{*}{$\begin{array}{l}\text { Sig. (2- } \\
\text { tailed) }\end{array}$} & \multirow{2}{*}{\begin{tabular}{|l} 
Mean \\
Difference
\end{tabular}} & \multirow{2}{*}{$\begin{array}{l}\text { Std. Error } \\
\text { Difference }\end{array}$} & \multicolumn{2}{|c|}{$\begin{array}{l}95 \% \text { Confidence Interval } \\
\text { of the Difference }\end{array}$} \\
\hline & & & & & & & & Lower & Upper \\
\hline $\begin{array}{l}\text { InterestednessEqual variances assumed } \\
\text { Equal variances not assumed }\end{array}$ & 6.272 & .014 & $\begin{array}{l}- \\
4.268 \\
4.268 \\
\end{array}$ & 78 & .000 & $\begin{array}{l}-1.02500 \\
-1.02500\end{array}$ & 24016 & $\begin{array}{l}-1.50312 \\
-1.50441\end{array}$ & $\begin{array}{l}-.54688 \\
-.54559\end{array}$ \\
\hline
\end{tabular}

The T-test Table 6 illustrates significance of .014 and $\geq .05$. In this regard the values are not reliable, either. TheTable demonstrated that the two groups were different in terms of their interest. In other words, the experimental group was more interested to learn in its definite mode of instruction as compared to the control group who received only bookbound instruction.

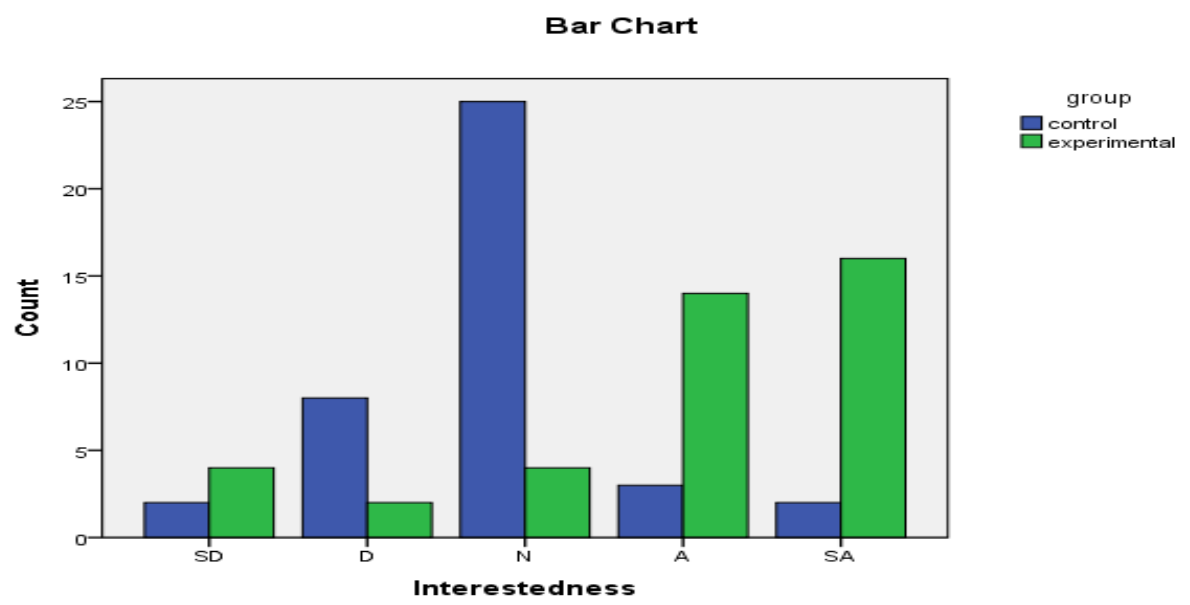

Figure 3

Figure 3 is a comparison of both experimental and control groups as relates to learning interest. The ways the bars are scattered shows in a glance the experimental groups' remarkable level of interest.

\section{CONCLUSION AND DisCUSSIONS}

Findings of the present study were in line with the research carried out bysome researchers in the past years. In this study, taking advantage of a film adaptation of a literary classic in theclassroomwas found to be highly contributive to the increase in the performance level of the learners, their interest, and their learning durability.

The findings of the present study suggest that watching films has a high correlation with students' performance on reading comprehension and multiple tests. Both the results of the T-test and the interview indicate that the experimental group outperformed the control group which again supports the meaningful and goal-oriented application of multimedia and films accompanied by books in the EFL classroom. Films, literature, and multimedia technology are believed to be effective in cultural transmission. The transmission of social heritage can serve pedagogical purposes. This mode of instruction and language teaching has gained a worldwide popularity and can be integrated into lessons, since ideas 
mentioned throughout films bear educational and cultural messages in them. Culture is an indispensable part of any language course due to the fact that language learning entails cultural education. In order to teach foreign culture, teachers can use a number of techniques and materials, among them are novels and films, which are considered as comprehensive text and audio-visual means to meet this goal.

The results are in line with Berwald's (1986) research, which suggested that the use of mass media in classroom environment is usefulas it promotes cultural awareness and successful interaction on various topics. The study also confirms Tanriverdi and Apak's (2008) argument, which states that media sources have an important effect on students as they encourage a positive attitude towards other cultures. Also, our findings affirm Grant S. Wolf's study (2006) which suggested that using video materials leads to inventive and fluent writing.

Clearly, without cultural awareness and knowledge of the culture of the target language, it is hardly possible to communicate accurately and effectively in a foreign context. Incorporatingliterature and filmsto the curriculum is an effective tool whichprovides the students with some cultural insight to the language they are learning. Well-organized strategies and appropriate techniquesalso pave the way for a teaching that results in a long-lasting and durable learning.

\section{REFERENCES}

[1] Backlund, P. (1990). Communication competence and its impact on public education (Report No. CS507279). Geographic Source: U.S.; Washington. CERIC Document Reproduction.

[2] Berwald, J. (1986). Au courant: Teaching French vocabulary and culture using the mass media (Language in education : theory and practice). Washington, D.C.: Center for Applied Linguistics, ERIC Clearinghouse on Languages and Linguistics.

[3] Duff, A. \& Maley, A. (1991). Literature (Resource book for teachers). Oxford: Oxford University Press.

[4] Hall, E.T. (1959). The Silent Language. Garden City, New York: Doubleday.

[5] Herron, C., Cole, S. P., Corrie, C., \& Dubreil, S. (1999). The effectiveness of video-based curriculum in teaching culture. The Modern Language Journal, 83(4), 518-533.

[6] Hinkel, E. (2001). Building awareness and practical skills to facilitate cross-Cultural communication. In Celce-Murcia, M. (ed.) (2001), Teaching English as Second or Foreign Language ( $3^{\text {rd }}$ edition). USA: Heinle and Heinle.

[7] Kramsch, C. (1993). Context and culture in language teaching. Oxford: Oxford University Press.

[8] Kramsch, C. (2013). Culture in foreign language teaching, Iranian Journal of Language Teaching Research, 1, pp. 57-78.

[9] Krasner, I. (1999). The role of culture in language teaching. Dialog on Language Instruction, 13(1-2), 79-88.

[10] Larsen-Freeman, D. (2001). Techniques and principles in language teaching ( $2^{\text {nd }}$ ed.). Oxford: Oxford University Press.

[11] Lessard-Clouston, M. (1997). "Towards an understanding of culture in 12/fl education." Ronko: K.G. Studies in English 25: 131-150. Retrieved from: http://iteslj.org/Articles/Lessard-Clouston-Culture.html on August, 2013.

[12] Peterson, Elizabeth and Coltrane, Bronwyn. "Culture In Second Language Teaching", Eric Digest, December 2003. Retrieved from: http://www.cal.org/resources/digest/digest_pdfs/0309peterson.pdf on December 2012.

[13] Moran, P. R. (2001). Teaching culture: perspectives in practice. Boston: Heinle \& Heinle.

[14] Scott, V. M., \& Huntington, J. A. (2000). Reading culture: Using literature to develop C2 competence. Foreign Language Annals, 35(6), 622-631.

[15] Seelye, H. (1984). Teaching culture: strategies for inter-cultural communication (Revised edition). Lincolnwood, IL: National Textbook Company.

[16] Steele, R. (1989). Teaching language and culture: Old problems and new approaches. In J. E. Tanriversi, B, Apak, O (2008), Culture and language teaching through media. Creating a global culture of peace: strategies for curriculum development and implementation, 2 -7 September, Antalyia, Turkey. 1- 156-168 Retrieved from Eric database.

[17] Stephens, J. L. (2001). Teaching culture and improving language skills through a cinematic lens: A course on Spanish film in the undergraduate Spanish curriculum. ADFL Bulletin, 33(1), 22-25.

[18] Tanrıverdi, B., Apak, Ö. (2008). Culture and Language Teaching through Media.WCCI13 ${ }^{\text {th }}$ World Conference in Education on "Creating a Global Culture of Peace: Strategies for Curriculum Development and Implementation".2-7 September. Antalya, Turkey. 1. 156-168. (Eds. Mirici, İ. H., AksuAtaç, B., Arslan, M.M., Kovalcikova, I.) Retrieved from ERIC database.

[19] Thanasoulas, Dimitrios. (2001). The importance of teaching culture in the foreign language classroom, Radical Pedagogy, pp. 1-25. Retrieved from: https://media.startalk.umd.edu/workshops/2009/SeattlePS/sites/default/files/files/The\%20Importance\%20Of\%20Teaching\%20 Culture\%20In\%20The\%20Foreign\%20Language\%20Classroom.pdf.

[20] Valdes, J. M. (ed.) 1986. Culture Bound: bridging the cultural gap in language teaching. Cambridge: Cambridge University Press.

[21] Wolf, G. S. Using video to develop writing fluency in low-proficiency ESL students, The Internet TESL Journal, Vol. XII, No. 8, August 2006.

[22] Zoreda, L. M. \& Vivaldo-Lima, J. (2008). Scaffolding Linguistic and Intercultural Goals in EFL with Simplified Novels and Their Film Adaptation. English Teaching Forum, 3: 22-29. 

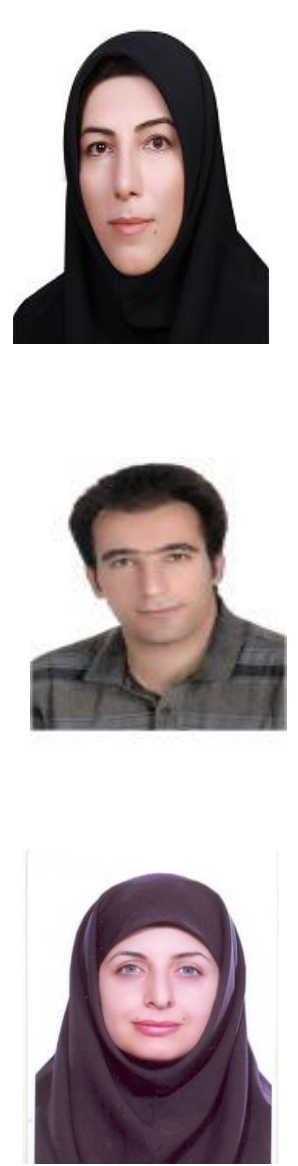

Robab Khosravi obtained her $\mathrm{PhD}$ in English Literature from Keele University, United Kingdom. She is currently Assistant Professor and the head of the English Language Department at University of Zanjan, Iran. Her main research interests are Modernism, the twentieth-century poetry (the work of T. S. Eliot in particular), critical theory, and aspects of postmodern thought and culture.
Mehdi Moharami is MA student of TEFL in University of Zanajn, Iran. He holds BA Degree from ErshadDamavand University (2011). He is teaching general English in different Language Schools. His main areas of interest are CALL, Literature teaching and News translation.

Giti Karimkhanlouei is an assistant professor of Zanjan University of Medical Sciences with 18 years of experience in teaching English language courses. Her research interests include: ESP, web-based learning and teaching, and Methodology of teaching. She has published variety of articles in internationally well-known journals. 